\title{
STUDY OF THE LICHENS OF THE MOROCCAN ATLANTIC COAST SAFI-ESSAOUIRA: BIOINDICATION OF AIR QUALITY AND LIMITING FACTORS
}

\author{
ESSILMI, M. ${ }^{*}$ - LOUDIKI, M. - EL GHARMALI, A. \\ Laboratory of Biology and Biotechnology of Microorganisms, Faculty of Sciences Semlalia, \\ University Cadi Ayyad, BP 23390, Marrakech, Morocco \\ *Corresponding author \\ e-mail: mohamed.essilmi@ced.uca.ma; phone: +212-63-217-4757 \\ (Received 23 ${ }^{\text {rd }}$ Dec 2018; accepted 22 ${ }^{\text {nd }}$ Feb 2019)
}

\begin{abstract}
In order to estimate the global air pollution of the Moroccan Atlantic coast Safi-Essaouira, we have used a qualitative approach based on the spatial distribution of saxicolous-calcicolous lichens that reflect special ecological and pollution conditions. The measurement of the beta diversity by the calculation of the Jaccard index makes it possible to quantify the similarity between the studied sites and has made it possible to measure the gradient of change of this diversity along an increasing gradient of the pollution supposed high in the industrial zone of the Safi city and decreasing going north or south. The hierarchical clustering has made it possible to partition the seven studied sites into two different classes and differentiate four groups of indicator species of poleotolerance and eutrophication. The identification of 36 species of lichens including indicator species of $\mathrm{SO}_{2}$ and $\mathrm{NOx}$ pollutions, the study of the impact of climate and pollution on the lichens biological spectrum, and the exploitation of the poleotolerance index and eutrophication index were necessary to elucidate the global air quality of the region.

Keywords: air pollution, beta diversity, poleotolerance index, eutrophication index, biological spectrum
\end{abstract}

\section{Introduction}

Since the beginning of the industrial era, human activities have been transforming the atmosphere of the globe more and more rapidly. Because of its geographical situation and its socio-economic development, Morocco is among the most vulnerable countries to the disturbances atmospheric. The cost of air degradation and its impacts has been estimated at 370 million USD per year (Worldwide air quality, 2018), which represents about $1.03 \%$ of Morocco's GDP in 2014. Ambient air pollution is responsible for nearly three quarters of this cost (Croitoru et al., 2017). In May 2016, World Health Organization in a report on urban air quality around the world, decreed Casablanca as the most polluted city of Morocco with a concentration level of small particles in the air of $61 \mu \mathrm{g} / \mathrm{m}^{3}$ (the maximum annual threshold tolerated by the WHO is $20 \mu \mathrm{g} / \mathrm{m}^{3}$ ); in the city of Safi, the concentration of small particles in the air is $21 \mu \mathrm{g} / \mathrm{m}^{3}$.

The use of lichens is one of the biological assessment approaches to environmental changes. At the regional scale, the lichens distribution is explained by the sensitivity to pollution (Bobbink et al., 2010; van denBerg et al., 2011), climate variations (Werth et al., 2005; Giordani et al., 2008; Hickling et al., 2006; Gottfried et al., 2012) and the continuity of the habitat (Selva, 1994; Hauck, 2011). Temporal and spatial variation in lichen diversity could be evaluated using beta diversity and similarity. This information could then be used to quantify anthropogenic impacts in a given region (Giordani et al., 2018).

Without root system, protective cuticle or regulating mechanisms of matter flow, nutrients and toxic substances dissolved in the atmosphere can be absorbed over the 
entire surface of the lichen thallus (Tyler, 1989; Bačkor et al., 2009). Since the early works of Nylander (1866), lichens are widely used as bioindicators for assessing air pollution (Garrec et al., 2002). Bioindication is an ecological approach that seeks to evaluate possible air disturbances from the presence/absence of key species in a specific lichenic survey.

The first catalog of Moroccan lichens was published by Werner and Gattefossé (1931) and includes 542 species. An important scientific study of Moroccan lichenic flora was conducted by Werner between 1931 and 1976. Egea (1996) in his catalog of lichens in Morocco reviews the studies of Moroccan lichen flora between 1879 and 1990 and gives a commented list of lichens in our country. In 2013, a synthesis on the lichens of the Rabat herbarium (RAB) was published by Ajaj et al. (2013).

The lichenic bioindication approaches used and still mostly use corticolous lichens. Comparatively, there are no bioindication studies of air quality using saxicolous lichens and especially saxicolous-calcicolous species. The reason we chose the calcicolous lichens is the ecological nature of the biotope of this study area harboring few corticolous and terricolous lichens, but showing a remarkable presence of calcicolous lichens.

The present study aims to study the lichen flora of the Atlantic coastal fringe of the Safi-Essaouira regions over $120 \mathrm{~km}$, to use the beta diversity measure to quantify the similarity between the studied sites, to study the climate impact and air pollutants $\left(\mathrm{SO}_{2}\right.$ and NOx) on this diversity and to exploit the poleotolerance index and the eutrophication index to highlight air pollution and map the overall air quality of the region.

\section{Materials and methods}

The Moroccan Atlantic coast Safi-Essaouira includes two urbanized areas (the city of Safi and the city of Essaouira) and less urbanized areas. Since the 1960s, it is home to a major industrial phosphate processing plant located in the south of the Safi, and accused of being one of the contributors to the deterioration of the air quality. In the near future, a coal-fired power plant, already installed $12 \mathrm{~km}$ south of Safi, will be operational by the end of 2018; it aims to cover 25\% of Morocco's electricity needs. The impacts of its construction and operation are expected to have an impact on the air quality caused by the dust generated during construction and the emissions that will be associated with coal combustion (sulfur, trace metals, radioactive elements, etc.).

The Atlantic coast Safi-Essaouira is characterized by a semi-arid climate with rains fall regularly in autumn and winter. The average annual rainfall is estimated at $350 \mathrm{~mm}$. Temperatures are moderate with an average annual value of $18{ }^{\circ} \mathrm{C}$. In August, the average temperature is $\mathrm{M}=25.7^{\circ} \mathrm{C}$; it is the hottest month of the year. The coldest month is January with an average temperature of $\mathrm{m}=8.9^{\circ} \mathrm{C}$. The drought period is 7 months, from April to October. The relative humidity of the air is on average between 70 and $80 \%$. The winds are particularly strong in the coastal zone. They are predominantly northwest and are frequent towards the end of the afternoon.

Seven sites were selected assuming an increasing air pollution gradient from nonurban areas to urban areas (Fig. 1). Lichen sampling focused on saxicolous species on limestone rock formations with homogeneous lichenic cover exposed to the air while avoiding sheltered rocky surfaces and surfaces directly exposed to the sea. Sometimes the species are taken with their support using a hammer and a chisel. 
The sampling campaigns covered the period from February 2016 to June 2016 and were updated in 2017 and 2018.

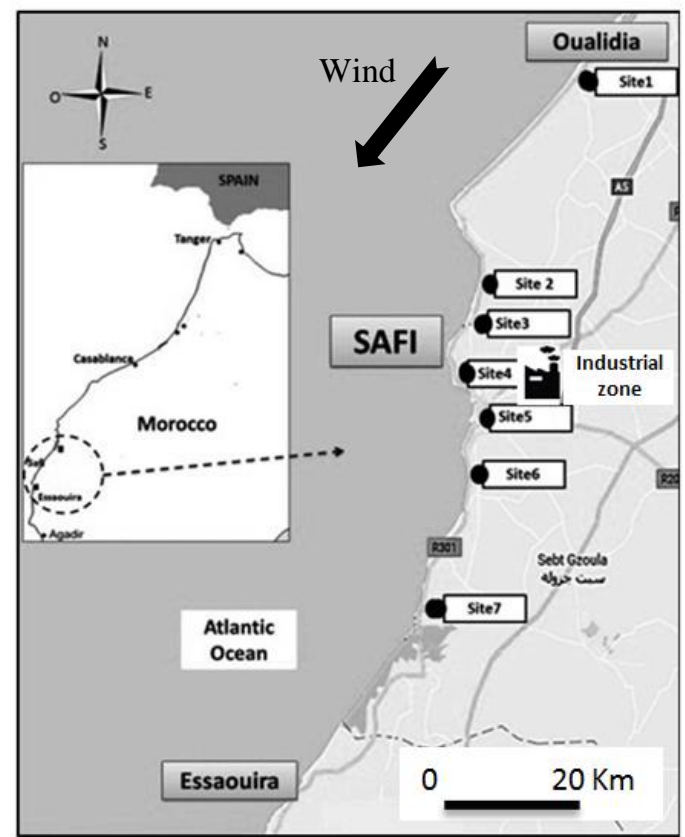

Figure 1. Location of the Safi-Essaouira coastline and the seven sites. The arrow indicates the general direction of the wind

Species determination was performed using a binocular loupe and an optical microscope for thallus sections. Different bibliographic sources were used in the determination, especially "Likenoj of Okcidenta Eŭropo" by Clauzade and Roux (1985): "Lichens: Biological study and illustrated flora", by Ozenda and Clauzade (1970) and "Guide of the lichens-350 species of lichens of Europe" (Thievant, 2001).

The following chemicals have been used in the determination of species: saturated potash for reactions on the thallus and medulla; chlorine in the form of sodium hypochlorite solution and paraphenylenediamine in stabilized solution.

Lichen diversity is also used for biomonitoring (Nimis et al., 1990; Loppi et al., 2004; Giordani, 2007; Giordani et al., 2014; Matos et al., 2017). To compare the studies sites in pairs, we considered the $\beta$ diversity that corresponds to the importance of species replacement along environmental gradients (Whittaker, 1972; Podani et al., 2013). The comparison of the number of taxa that are unique to each site makes it possible to measure the gradient of change of diversity along the increasing gradient of the supposed pollution from the industrial zone and going to the north or the south.

As bioindication approach, the method of the index of atmospheric purity (IAP) has not been used; this method requires the determination of the entire lichenic flora. The method of Hawksworth and Rose, established in the British Isles (1970), is inapplicable in the Mediterranean (Semadi et al., 1995). The method of Van Haluwyn and Lerond (1986), although adaptable to all the study areas, has been validated only for the corticolous species.

To overcome this situation, and considering the available means, we have selected among recent methods the studies of Nimis and Martellos (2017) which attributed to 
different species of lichens a poleotolerance index and an eutrophication index. This work done in Italy has the advantage of being interested in lichens from Mediterranean region whose ecological characteristics are close to those of Morocco, It is also a solution in the absence of cartographic studies of the overall air quality using saxicolous lichens and especially saxicolous-calcicolous and facing the absence of similar works on the Moroccan territory.

To illustrate the arrangement of sites and species of lichens studied in terms of ecological parameters, we have processed the databases using the SPSS statistics 20.0 software and the R software using the FactoMineR and factoextra package that divide datasets, containing $\mathrm{n}$ observations, into a set of $\mathrm{k}$ groups (ie clusters) in which each cluster is represented by the center or the means of the data points belonging to the cluster (K-means clustering).

\section{Results}

\section{Beta diversity and spatial bioindication of air quality}

It is evident that the exhaustive study of all lichens in the region cannot be established because of the difficulty of identifying all species in particular crustose saxicolous calcicolous lichens. The number of taxa identified in the study area is 36 saxicolous lichens (Table Al in the Appendix). As we move further away from the industrial zone (Site 4), the number and diversity of lichens increases.

Morphologically, fruticose forms such as Roccella phycopsis and Ramalina pollinaria disappear $20 \mathrm{~km}$ far from the $\mathrm{S} 4$ site. The foliose forms penetrate up to around $4 \mathrm{~km}$ from the $\mathrm{S} 4$ site, only a few crustose forms settle in the $\mathrm{S} 4$ site. Of the 36 calcicolous species there is a diversity of 22 different genera. This diversity is between 36 and 3 species per station. There are 30 species of crustose, 4 foliose species and 2 fruticose species.

Among the indices used to measure beta diversity, we used the Jaccard index (1908) to quantify the similarity between the studied sites. The similarity increases with the value of the index which takes the value 0 when two sites have no similarity (no species in common) and 1 when the similarity is maximal (all the species are in common). The equation of this index is $(E q .1)$ :

$$
S j=\frac{c}{a+b+c}
$$

$\mathrm{c}=$ number of common species

$\mathrm{a}=$ species of the site $\mathrm{a}$

$\mathrm{b}=$ species of the site $\mathrm{b}$

Table 1 illustrates the similarity matrix between sites taken two by two: The two most similar sites are $S 1$ and $S 7(S j=1)$, the least similar are $S 4$ and $S 1(S j=0)$. A hierarchical K-means clustering has allowed partitioning the sites according to their degree of similarity: On the dendrogram (Fig. 2), a cutoff passing through the value combination distance 5 individualizes three groups of sites: group 1 "S1, S2, S6 and S7", group 2 "S3 and S5" and group3 "S4".

These results reflect the grouping of these sites according to the habitat quality they represent. The study of beta diversity via the similarity index and the hierarchical 
ascending classification (Fig. 2) show a differentiation of these sites into three groups of lichenic biodiversity.

Table 1. Similarity matrix of the studied sites. (Performed by IBM SPSS statistics 20.0 software)

\begin{tabular}{l|l|l|l|l|l|l|l}
\hline & Site1 & Site2 & Site3 & Site4 & Site5 & Site6 & Site7 \\
\hline Site1 & 1.000 & 0.926 & 0.556 & 0.000 & 0.333 & 0.815 & 1.000 \\
Site2 & 0.926 & 1.000 & 0.670 & 0.032 & 0.333 & 0.835 & 0.830 \\
Site3 & 0.556 & 0.670 & 1.000 & 0.111 & 0.661 & 0.761 & 0.689 \\
Site4 & 0.000 & 0.032 & 0.111 & 1.000 & 0.222 & 0.049 & 0.022 \\
Site5 & 0.333 & 0.333 & 0.661 & 0.222 & 1.000 & 0.453 & 0.362 \\
Site6 & 0.815 & 0.835 & 0.761 & 0.049 & 0.453 & 1.000 & 0.921 \\
Site7 & 1.000 & 0.830 & 0.689 & 0.022 & 0.362 & 0.921 & 1.000 \\
\hline
\end{tabular}

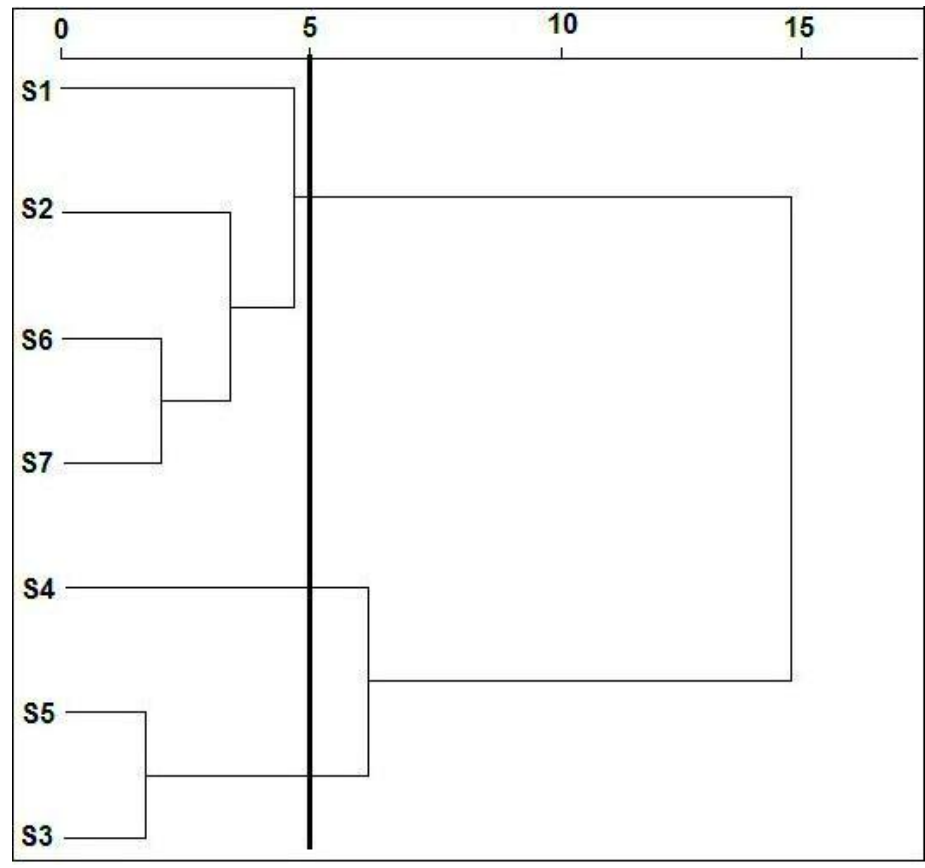

Figure 2. Cluster dendrogram of inter sites similarity. (Performed by IBM SPSS statistics 20.0 software)

\section{Use of the poleotolerance index and the eutrophication index}

Nimis and Martellos (2017) have attributed to a variety of lichen species an index of poleotolerance: This value points to the tendency of a lichen to occur in areas with different degrees of human disturbance. It is expressed on 4 classes, as follows:

$3=$ species occurring in heavily disturbed areas, including. large towns.

$2=$ species occurring in moderately disturbed areas (agricultural areas, small settlements etc.).

$1=$ species occurring in natural or semi-natural habitats.

$0=$ species which exclusively occur on old trees in ancient, undisturbed forests. Contrary to the other values, this one has been assigned to epiphytic species only, since it is useful to point out indicators of long ecological continuity of forests. 
The authors also proposed an eutrophication index: this value expresses the degree of nitrogen pollution, including deposition of dust and nitrogen compounds, there are 5 values:

$1=$ no eutrophication

$2=$ very weak eutrophication

$3=$ weak eutrophication

$4=$ rather high eutrophication

$5=$ very high eutrophication (Table A2 in the Appendix).

The species with a low eutrophication index are confined in the S1, S2, S6 and S7 sites (Table A2): This is the case of Acrocordia conoidea and Parabagliettoa cyanea. Although its poleotolerance index is low to medium (1-2), others species with an eutrophication index of 2-3 like Coscinocladium gaditanum can grow in sites near industrial zone (Sites S3 and S5). Only species with an index of 4-5 such as Caloplaca citrina and Lecania erysibe seem to support the air quality of the S4 site (industrial zone).

\section{Discussion}

Due to their close dependence on the atmosphere for their metabolic processes (Rundel, 1988; Nash, 1996), lichens are strongly influenced by environmental variables, which affect their richness and distribution. The species composition and its richness is often used for spatial analysis in ecosystems (Brunialti et al., 2003; Kapusta et al.,2004; Giordani, 2006; Will-Wolf et al., 2006). Numerous studies have shown that different disturbances of the biotope have a limiting effect on lichen communities: $\mathrm{SO}_{2}$ in the 1970s in Great Britain (Hawksworth and Rose1970), dust (Loppi and De Dominicis, 1996,), fire (Longán et al., 1999) in the Mediterranean regions, and nitrogen compounds in the Netherlands (van Dobben et al., 2001; van Herk, 2002). The differences in species richness between the studied sites (S1 to S7) can be correlated with the action of environmental fluctuations (Seaward1977; Nash, 1996).

\section{Bioindication of climate as a limiting factor}

The study of the biological spectrum of calcicolous lichens harvested in unpolluted rural sites (S1 and S7) shows that crustose forms reach a frequency of $80 \%$ (Fig. 3). This value reflects the bioclimatic nature of the region. According to the climatic data we can calculate the aridity Martonne index (I) (Eq. 2; De Martonne, 1923) and the pluviometric Quotient of Emberger (Q) (Eq. 3; Emberger, 1955):

$$
I=\frac{P}{T+10}
$$

where $\mathrm{I}=12.07$.

$$
Q=\frac{2000 P}{M^{2}-m^{2}}
$$

where $\mathrm{Q}=57.57$. 
To correlate the biological spectrum of lichens with the ecological conditions of the biotope Renaut et al. (1968) reported, in a study conducted in Morocco, that a biological spectrum with $50 \%$ crustose forms corresponds to $\mathrm{Q}=80$, with $70 \%$ crustose forms $\mathrm{Q}$ is close to 60 . Finally with $80 \%$ crustose forms Q is less than 60 .

In our study $\mathrm{Q}=57.57$ and the biological spectrum of harvested lichens is dominated by crustose forms $(80 \%)$ which corresponds to the observations made by Renaut et al. (1968). On the other hand, the regional semi-arid climate $(I=12.07$ and $Q=57.57)$ imposes a steppe-type vegetation which explains a relatively small number of trees that can support corticolous lichens. The dominance of limestone rocks combined with a semi-arid climatic is such that our study biotope is colonized by calcicolous lichens.

\section{Bioindication of the pollution as limiting factors}

The closer we get to the industrial zone (site S4), the more the lichenic biological spectrum is dominated by crustose forms (Fig. 3). Fruticose lichens are more sensitive to pollution than foliose and crustose forms.

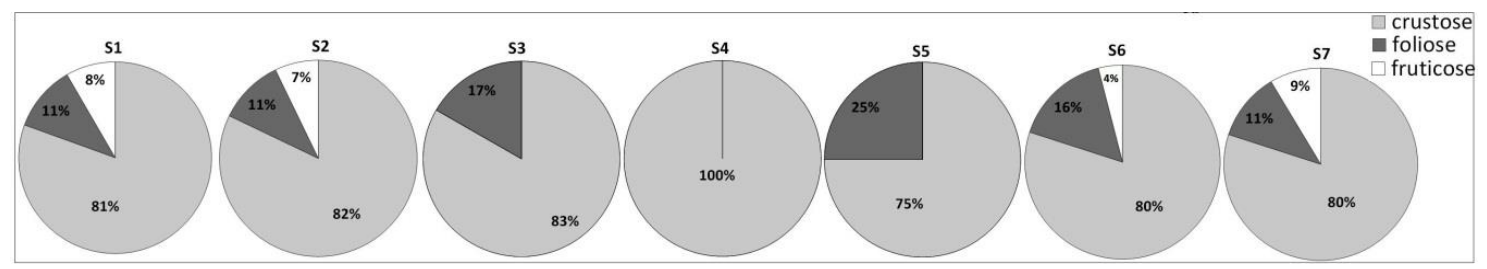

Figure 3. Spatial variation of the biological spectrum of harvested lichens, according to the distance to Safi industrial zone (site S4)

Studies have shown a relationship between the lichen growth form and its resistance to pollution. Maizi et al. (2017) reported that the Fruticose lichen Ramalina is more sensitive to metal trace element than the foliose lichen Xanthoria parietina and the absorption capacity of MTE is different depending on the type of thallus (foliose or fruticose).

Gauslaa et al. (2002) reported that in polluted sites, the medullary metabolites in Ramalina have been reduced and lichen is less protected. Weissman et al. (2006) reported that under conditions of low pollution, occur in Ramalina antioxidant activities as protective mechanisms. However, after prolonged exposure, these protective mechanisms are overwhelmed and damage to cellular components begins to accumulate. It follows a decrease in antioxidant activities and degradation of lichen. The disappearance of the fruticose forms from the site S3 and S4 can be related to the death of these lichens as a result of damage to their biological components caused by air pollution.

\section{Bioindication of $\mathrm{SO}_{2}$ as a limiting factor}

To give credibility to the bioindication approaches adopted in this work, the results of a research project on the bioaccumulation of metallic trace elements by lichens (Essilmi et al., 2018) made it possible to quantify and characterize air pollution trends in the seven studied sites. These results and other measurements of air quality, shown in Table 2, present exact values of air pollution and its distribution in space, which must be verified and supplemented by lichen bioindication. 
Table 2. Some measurements of air pollution in the Safi-Essaouira region

\begin{tabular}{c|c|c|c|c|c|c|c|c|c}
\hline $\begin{array}{c}\text { Measurement } \\
\text { approaches }\end{array}$ & Pollutants & S1 & S2 & S3 & S4 & S5 & S6 & S7 & References \\
\hline \multirow{2}{*}{$\begin{array}{c}\text { Measuring } \\
\text { instruments }\end{array}$} & $\mathrm{SO}_{2} \mu \mathrm{g} / \mathrm{m}^{3}$ & $<5$ & 5 & 35 & 50 & 35 & $\mathrm{NA}$ & $\mathrm{NA}$ & $\begin{array}{c}\text { OCP } \\
(2011)\end{array}$ \\
\cline { 2 - 9 } & $\mathrm{NO}_{\mathrm{x}} \mu \mathrm{g} / \mathrm{m}^{3}$ & $\mathrm{NA}$ & $\mathrm{NA}$ & 53.62 & 53.62 & $\mathrm{NA}$ & $\mathrm{NA}$ & $\mathrm{NA}$ & $\begin{array}{c}\text { Ministry of } \\
\text { Energy } \\
(2014)\end{array}$ \\
\hline $\begin{array}{c}\text { Lichenic } \\
\text { bioaccumulation } \\
\text { in Xanthoria } \\
\text { calcicola }\end{array}$ & $\mathrm{Cd}$ & 0.000 & 0.178 & 0.301 & 0.532 & 0.210 & 0.191 & 0.154 & 7.159 \\
\hline $\mathrm{Cb}$ & 1.719 & 6.171 & 15.756 & 30.187 & 5.192 & 7.579 & 2.443 & $\begin{array}{c}\text { Essilmi et } \\
\text { al. (2018) }\end{array}$ \\
\hline
\end{tabular}

$\mathrm{NA}=$ not available

The "Office chérifien des phosphates" group (OCP, 2011), owner of the chemical industry "Maroc Phosphore", reported in its 2011 report, the measurements of $\mathrm{SO}_{2}$ of the air (Table 2). In its 4th report of 2014, the Moroccan Ministry of Energy (2014) reported an annual average $\mathrm{NO}_{2}$ of $53.62 \mu \mathrm{g} / \mathrm{m}^{3}$, in Safi city, which exceeds the annual norm of $50 \mu \mathrm{g} / \mathrm{m}^{3}$.

In the absence of studies on the susceptibility of calcicolous lichens to pollution, the cortical form of Xanthoria parietina is an example of nitrophytic lichen (NO2) and sulfur toxitolerant $\left(\mathrm{SO}_{2}\right)$ which disappears at a high concentration of $\mathrm{SO}_{2}$ sulfur dioxide $\geq 67 \mu \mathrm{g} / \mathrm{m}^{3}$ (Wetmore, 1983) (Table 3). In 1970 Hawksworth and Rose reported that Ramalina pollinaria disappear at $38.78 \mu \mathrm{g} / \mathrm{m}^{3}$, in 2014 Duman et al., reveal that Ramalina pollinaria is sensitive to pollution stresses as evernia prunastri. The disappearance of Xanthoria parietina and Ramalina Pollinaria from the S4 site confirms the rate of $50 \mu \mathrm{g} / \mathrm{m}^{3}$ of $\mathrm{SO}_{2}$ reported by the measurements. On the other hand, the disappearance of Physcia adscendens from S4 may be due to its oligotrophy for NOx.

Table 3. Examples of SO2 and NOx tolerance threshold in lichens

\begin{tabular}{c|c|c}
\hline & SO2 tolerance threshold & NOx tolerance threshold \\
\hline Xanthoria parietina & $\begin{array}{c}\text { Absent at } 67 \mu \mathrm{g} / \mathrm{m}^{3} \\
\text { (Wetmore, 1983) }\end{array}$ & $\begin{array}{c}\text { Eutroph with a high N requirement, peak } \\
\text { detection frequency occurs at 6.1 kg N per } \\
\text { ha per year (McCune and Geiser, 2009) }\end{array}$ \\
\hline Ramalina pollinaria & $\begin{array}{c}\text { Absent at } 38.78 \mu \mathrm{g} / \mathrm{m}^{3} \\
\text { (Hawksworth and Rose, 1970) }\end{array}$ & $\begin{array}{l}\text { Oligotroph with a low N requirement, peak } \\
\text { detection frequency occurs at 1.1 kg N per } \\
\text { ha per year (McCune and Geiser, 2009) }\end{array}$ \\
\hline Physcia adscendens & $\begin{array}{c}\text { Absent at } 87.24 \mu \mathrm{g} / \mathrm{m}^{3} \\
\text { (Wetmore, 1983) }\end{array}$ & $\begin{array}{c}\text { Oligotroph with a low N requirement, peak } \\
\text { detection frequency occurs at 1.1 kg N per } \\
\text { ha per year (McCune and Geiser, 2009) }\end{array}$ \\
\hline
\end{tabular}

The Hawksworth and Rose scale showed absolute $\mathrm{SO}_{2}$ concentrations as the only factor influencing lichen species rather than the acidity of their support. Several studies have tried to find an explanation of the physiological impact of $\mathrm{SO}_{2}$ on lichens. The sensitivity of lichens living on acid bark, tested in the laboratory, showed the same physiological symptoms as in the field. However, for species living on alkaline supports 
the correlation appeared to be negative (Baddeley et al., 1972; Ferry et al.,1979). Most nitrophytic species appear to have low sensitivity to the toxic effects of $\mathrm{SO}_{2}$; their only requirement is a high $\mathrm{pH}$ of the support. Van Herk (2001) reported that an increase in the $\mathrm{pH}$ of the substrate appears to be the main cause of the considerable increase in the number of nitrophytic species and the

disappearance of acidophyte species during the 1990s in the Netherlands. Other studies suggest that species tolerant to $\mathrm{SO}_{2}$ are sensitive to $\mathrm{NH}_{3}$ and vice versa (Van Dobben, 1999).

It has been found that, with considerable $\mathrm{SO}_{2}$ pollution in an area, the first loss of the same $\mathrm{pH}$-sensitive lichens occurs on birches and conifers (acid bark and low buffering capacity); the next loss on oaks and sycamore (intermediate acidity and buffering capacity); the last on trees like elm (alkaline bark and high buffering capacity). In general, an alkaline substrate such as basic bark or limestone counteracts the acidity of $\mathrm{SO}_{2}$ pollution (New York State's Urban Forestry council 2018).

Methods using the diversity of lichen species to estimate $\mathrm{SO}_{2}$ air pollution should be used with caution. This is the case of calcicolous lichens studied in this work and living on a limestone support whose $\mathrm{pH}$ is alkaline. The decrease in lichen species richness in the S3 and S4 sites can be correlated with an increase in the $\mathrm{pH}$ of the support; the disappearance of oligotrophic species such as Ramalina pollinaria and Physcia adscendens indicates that the increase in $\mathrm{pH}$ is due to an increase in NOx levels in the air, this indication is confirmed by the annual rate of $53.62 \mu \mathrm{g} / \mathrm{m}^{3}$ of $\mathrm{NO}_{2}$ which exceeds the annual norm of $50 \mu \mathrm{g} / \mathrm{m}^{3}$ (Ministry of Energy (2014). Current evidences suggest that increases in substrate $\mathrm{pH}$ due to $\mathrm{NH}_{3}$ may be a driving force of change of the lichenic communities (Wolseley et al., 2006).

\section{Bioindication of human disturbance and nitrogen pollution}

The use of the poléotolérance index and the eutrophication index show that species with a low poleotolerance index $(\mathrm{PI}=1)$ and a low eutrophication index $(\mathrm{EI}=1)$ are absent in the S3 and S4 sites; Species with low poleotolerance index and low eutrophication index are restricted to sites S1, S2, S6 and S7 indicating low levels of anthropogenic disturbance and low eutrophication; this is the case of Acrocordia conoidea and Parabagliettoa cyanea. Only species with high value indices, such as Caloplaca citrina and Lecania erysibe, can withstand high levels of eutrophication and anthropogenic disturbances and are able to settle in site S4 indicating high pollution.

The HCPC statistical analysis (Hierarchical Clustering on Principal Components) (Husson et al., 2010), allows to group lichens according to 4 ecological variables: Poléotolérance index (PI), eutrophication index (EI), the biological spectrum and the specific présence in each site (Figs. 4, 5 and 6 ).

There are 4 types of species profile indicator of poleotolerance and eutrophication (Table 4):

- Species in natural habitats without disturbance and without eutrophication (Cluster 1)

- Species present in moderately disturbed habitats and support low eutrophication (Cluster 2)

- Nitrophytic species present in moderately disturbed areas (Cluster 3)

- Highly nitrophytic species present in heavily disturbed areas (Cluster 4) 
Depending on the value of these indices we can classify the sites S1 to S7 into 3 classes (Table 5).

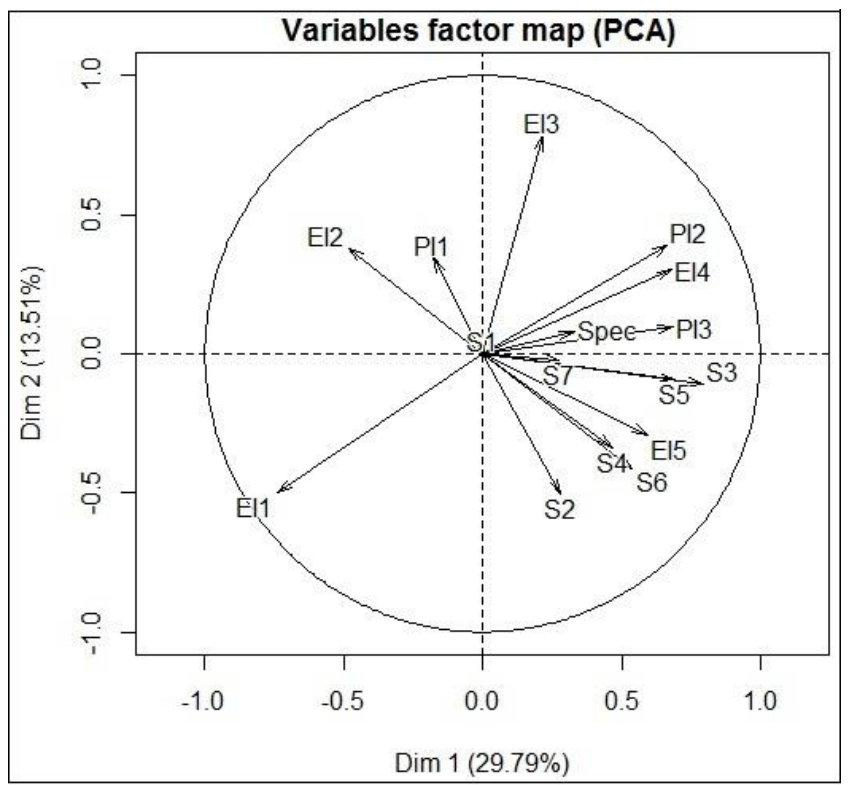

Figure 4. Circle of correlation between 4 variables: Poléotolérance index (PI), eutrophication index (EI), the biological spectrum and the specific presence/absence in each site. (Performed by $R$ software)

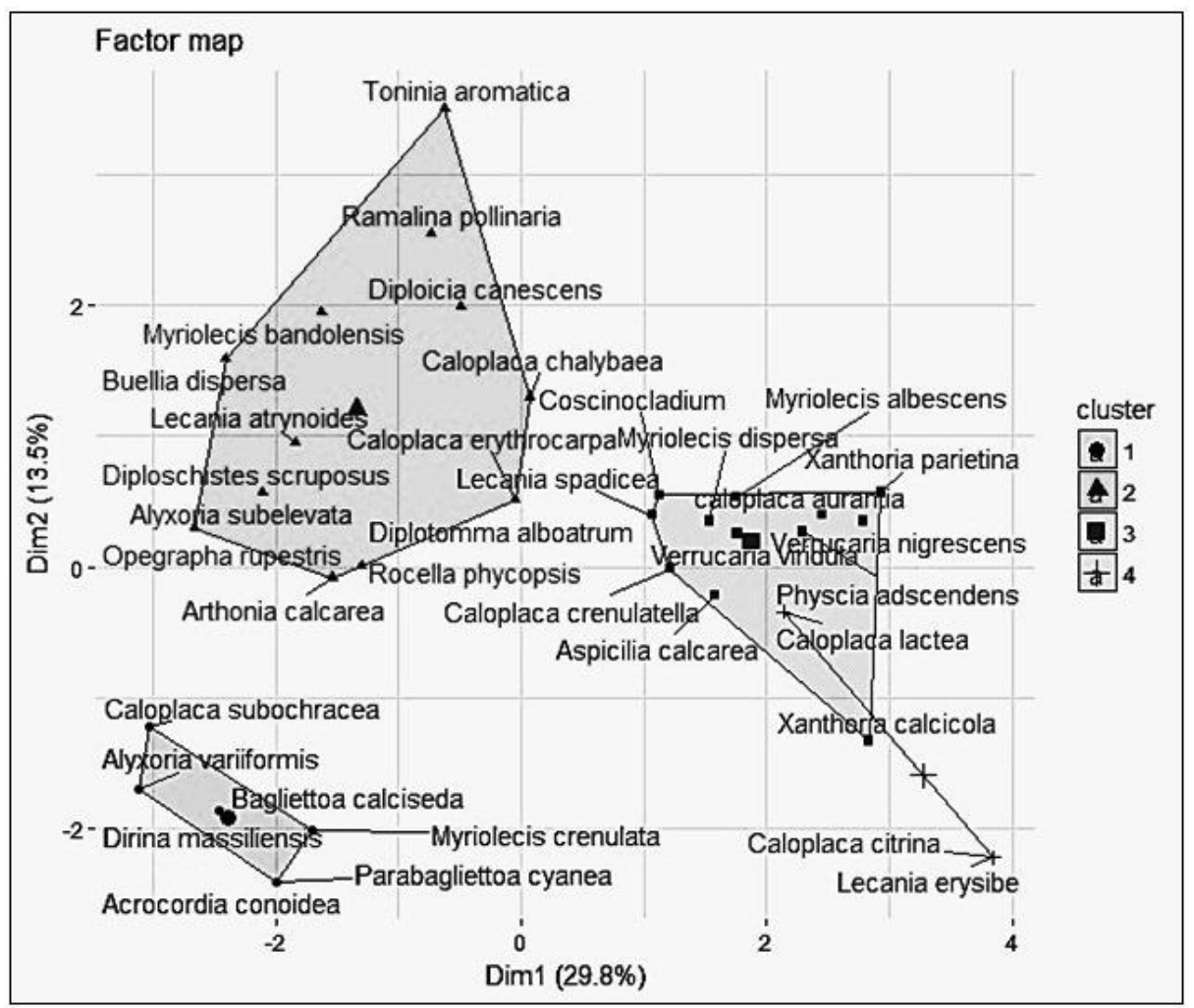

Figure 5. Differentiation of four species profile indicator of poleotolerance and eutrophication. (Performed by $R$ software) 


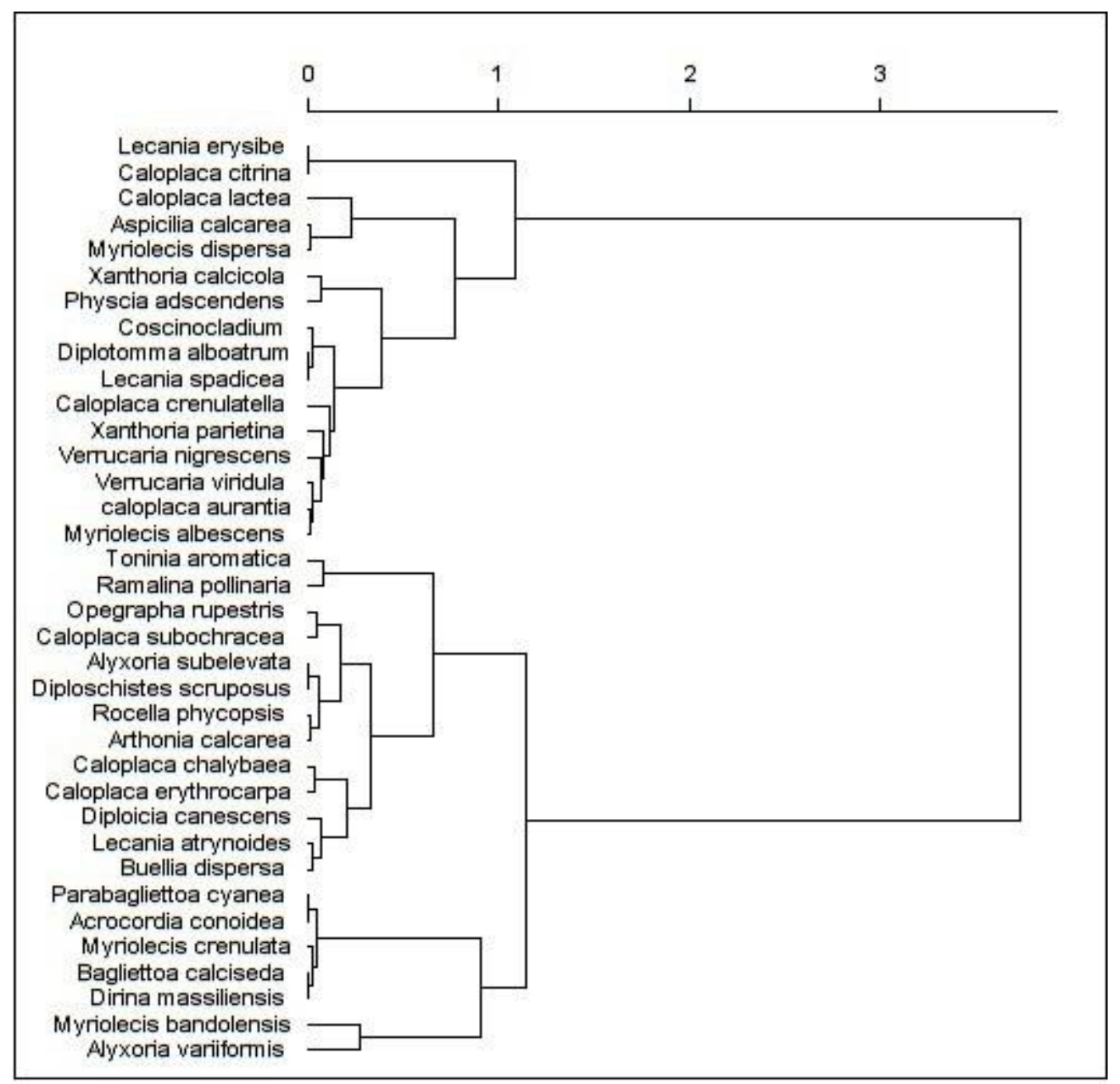

Figure 6. Hierarchical clustering of studied lichens according to their, PI, EI, Biological spectrum and specific presencelabsence in each site. (Performed by $R$ software)

Table 4. Differentiation of four groups of Poléotolérance and eutrophication species indicator

\begin{tabular}{c|c|c|c}
\hline Cluster 1 & Cluster 2 & Cluster 3 & Cluster 4 \\
\hline Caloplaca subochracea & Alyxoria subelevata & Aspicilia calcarea & Caloplaca lactea \\
Alyxoria variiformis & Arthonia calcarea & Caloplaca aurantia & Lecania erysibe \\
Dirina massiliensis & Buellia dispersa & Caloplaca crenulatella & Caloplaca citrina \\
Bagliettoa calciseda & Caloplaca chalybaea & Coscinocladium gaditanum & \\
Myriolecis crenulata & Caloplaca erythrocarpa & Diplotomma alboatrum & \\
Parabagliettoa cyanea & Diploicia canescens & Lecania spadicea & \\
Acrocordia conoidea & Diploschistes scruposus & Myriolecis albescens & \\
& Lecania atrynoide & Myriolecis dispersa & \\
& Myriolecis bandolensis & Physcia adscendens & \\
& Opegrapha rupestris & Verrucaria nigrescens & \\
& Ramalina pollinaria & Verrucaria viridula & \\
& Rocella phycopsis & Xanthoria calcicola & \\
& Toninia aromatica & Xanthoria parietina & \\
\hline
\end{tabular}


Table 5. Classification of sites according to the poleotolerance index and the eutrophication index of harvested lichens

\begin{tabular}{c|c|c|c|c|c}
\hline Classes & Sites & Species indicator & PI & EI & Degrees of disturbance \\
\hline \multirow{4}{*}{$\mathbf{1}$} & S1 & Acrocordia conoidea & 1 & 1 & \\
& S2 & Dirina massiliensis & 1 & $1-2$ & - Natural or semi-natural habitats \\
& S6 & Parabagliettoa cyanea & 1 & 1 & - Very low eutrophication \\
& S7 & & & & \\
\hline \multirow{3}{*}{2} & & Caloplaca erythrocarpa & $1-2$ & $2-3$ & - Areas with moderate human \\
& S3 & Diplotomma alboatrum & $1-2$ & $3-4$ & disturbance \\
& S5 & Lecania spadicea & $1-2$ & $3-4$ & - Low eutrophication \\
\hline \multirow{3}{*}{3} & & Caloplaca citrina & $1-3$ & $4-5$ & The disappearance of all the species \\
& \multirow{3}{*}{ S4 } & Lecania erysibe & $1-3$ & $4-5$ & and the presence of these 2 species \\
& & indicates that they are zones with \\
& & Canthoria calcicola & $1-2$ & $4-5$ & Strong disturbance of anthropic origin \\
& & Caloplaca crenulatella & $1-2$ & 4 & and strong eutrophication \\
\hline
\end{tabular}

Despite its low poleotolerance index $(\mathrm{PI}=1-2)$, Xanthoria calcicola has been identified at the periphery of the S4 site characterized by a high degree of human disturbance: the explanation can be approached according to the following considerations:

- The effect of pollution on lichen depends on the $\mathrm{pH}$ of the substrate. Soils containing calcium and limestone are better able to neutralize sulfuric and nitric acid deposits than siliceous soils. The calcareous substrate moderates the effects of an acid pollution by $\mathrm{SO}_{2}$ and NOx. The sulfuric acid reacts with the limestone in a neutralization reaction.

Limestone: $\mathrm{CaCO}_{3}+\mathrm{H}_{2} \mathrm{SO}_{4}-->\mathrm{CaSO}_{4}+\mathrm{H}_{2} \mathrm{CO}_{3}$

The calcium sulfate is soluble in water and hences the limestone dissolves and crumbles.

$\mathrm{H}_{2} \mathrm{CO}_{3}-->\mathrm{CO}_{2}+\mathrm{H}_{2} \mathrm{O}$

The original acid (hydrogen ions) have been converted to water in these reactions.

- Thanks to a high tolerance to eutrophication, species with low poleotolerance manage to settle in heavily polluted areas; Lachat et al. (2011) report that eutrophication promotes the differential development of some lichen species that resist the effects of pollution. Recently it has been shown that lichen community composition near motorways is shifting towards species associations with more nitrophytic lichens (Madl, 2009). Generally, changes in $\mathrm{N}$-deposition affect the composition of plant diversity and may induce a dominance of nitrophytic species over those species that are more susceptible to nitric-enrichment in nutrient-poor habitats (Frati et al., 2007; Bowman et al., 2006; Riddell et al., 2011). One mechanism leading to this extreme sensitivity of some lichens to excessive supply of nitrogen compounds may be the ability to bind such compounds within cell walls until the concentrations become toxic by causing electrolyte leakage as was shown for Evernia prunastri by Munzi et al. (2009a, b).

- In the dried condition the lichens were clearly more resistant. Xerophytic species may appear to be more tolerant to $\mathrm{SO}_{2}$ pollution only because they are 
dry for longer periods of time during which they are quite tolerant (Beekley et al., 1981). Under low relative humidity conditions, lichens are more resistant to high $\mathrm{SO}_{2}$ concentrations.

Sites $\mathrm{S} 1$ and $\mathrm{S} 2$ are characterized by the development of crustose, foliose and fruticose lichens, the fruticose form is represented by only two species: Ramalina pollinaria and Roccella phycopsis which disappear from sites S3, S4 and S5.

Foliose species such as Xanthoria calcicola and Coscinocladium gaditanum were collected at the S3 and S5 sites but absent at S4. Only crustose forms such as Lecania erysibe and caloplaca citrina persist in S4. Overall, there is a decrease in the abundance and diversity of lichens with urbanization and industrialization.

Three categories of calcicolous lichens can be distinguished:

- Species "resistant" to air pollution, encountered in the S4 site

- Moderately resistant species that disappear from S4

- Poleophobe species whose presence is limited to sites S1 S2, S6, and S7

It can be concluded that there is a pollution gradient whose maximum in the S4 site and which decreases as we moves north or south. The results of the two bioindication approaches "Presence/absence of key species" and the "Use of the poleotolerance index and the eutrophication index" have led to the conclusion that in the industrial zone (site S4) the air quality is disturbed by urbanization and industry, the further we get from the S4 site, the better the air quality, and $20 \mathrm{~km}$ from the S4 site we have good air quality. Thanks to these results it is possible to model a global map of air pollution in the study area (Fig. 7).

It is clear that in nature lichen responds to a mixture of pollutants that may have synergistic, protective or harmful effects on it. The lichens are different in their sensitivity to pollutants and their response to pollutant mixtures (Hyvärinen et al., 1992; Gilbert, 1986; Farmer et al., 1992).

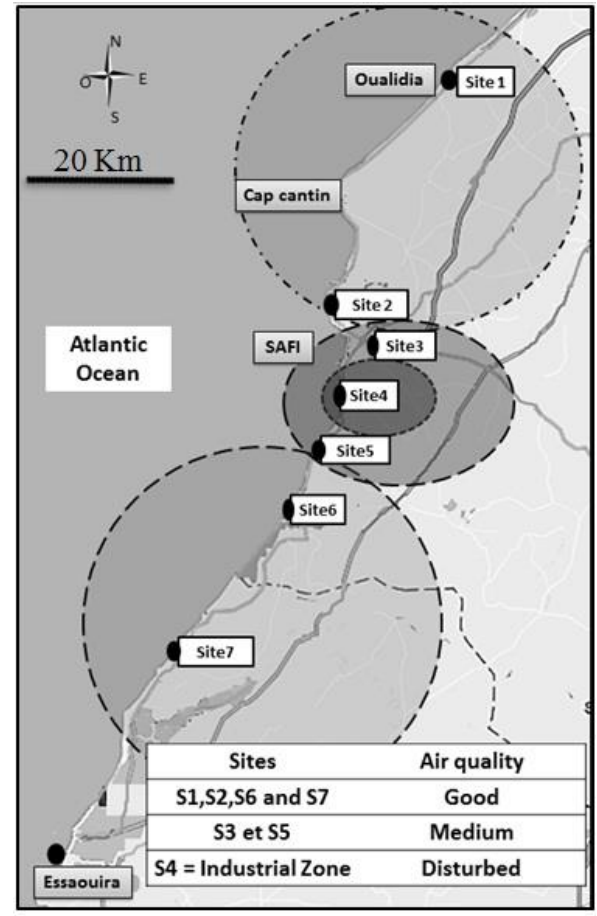

Figure 7. Delineation of the air quality of the studied sites 


\section{Conclusion}

The study of beta diversity via the similarity index revealed a gradual decrease in beta diversity due to an increasing gradient of pollution, while the hierarchical clustering has allowed a partitioning of the sites studied into three groups of lichenic biodiversity. The bioindication study using the calcicolous lichens has allowed to deduce that sites S3, S4 and S5 S5 are in a circle of $20 \mathrm{~km}$ diameter whose center is the industrial zone and where air quality is more or less disrupted by urbanization and industry; while sites S1, S2, S6 and S7 are outside this circle indicating good air quality. The further away from the industrial site (S4), the greater the number and diversity of lichens: The fruticose and foliose forms disappear at $20 \mathrm{~km}$ and $4 \mathrm{~km}$ respectively around site S4. Only a few crustose forms inhabit the S4 site, however the lichenic desert is not observed.

By using the poleotolerance index and the eutrophication index we conclude that the S4 site suffers a strong anthropogenic disturbance and a strong eutrophication: Further we get from this site, more the environment becomes natural and its rate of eutrophication decreases. This approach has shown that medium poleotolerance combined with high eutrophication resistance allows some calcicolous lichen species, such as Xanthoria Calcicola, to withstand areas of high pollution.

The present study confirms that lichens are good indicators of climatic parameters: the abundance of crustose forms and the low presence of fruticose and foliose forms, indicates an arid character of the regional climate.

\section{REFERENCES}

[1] Ajaj, A., Ouazzani, T., Benkirane, R., Douira, A. (2013): Contribution to the update of the catalogue of lichenized and lichenicolous fungi in Morocco. - J. Animal Plant Sciences 19(3): 2961-3025.

[2] Backor, M., Loppi, S. (2009): Interactions of lichens with heavy metals. - Biol Plantarum 53: 214-222.

[3] Baddeley, M. S., Ferry, B. W., Finegan, E. J. (1972): The effects of sulphur dioxide on lichen respiration. - Lichenologist 5: 283-291.

[4] Beekley, P., Hoffman, G. (1981): Effects of sulfur dioxide fumigation on photosynthesis, respiration, and chlorophyll content of selected lichens. - The Bryologist 84(3): 379-389. DOI: 10.2307/3242857.

[5] Bobbink, R., Hicks, K., Galloway, J., Spranger, T., Alkemade, R., Ashmore, M., Bustamante, M., Cinderby, S., Davidson, E., Dentener, F. et al. (2010): Global assessment of nitrogen deposition effects on terrestrial plant diversity: a synthesis. Ecological Applications 20: 30-59.

[6] Bowman, W. D., Gartner, J. R., Holland, K., Wiedermann, M. (2006): Nitrogen critical loads for alpine vegetation and terrestrial ecosystem response: are we there yet? - Ecological Applications 16: 1183-1193. http://dx.doi.org/10.1890/10510761(2006)016[1183:NCLFAV]2.0.CO;2.

[7] Brunialti, G., Giordani, P. (2003): Variability of lichen diversity in a climatically heterogeneous area (Liguria, NW Italy). - Lichenologist 35: 55e69.

[8] Clauzade, G., Roux, C. (1985): Lichens from western europe [Likenoj De Okcidenta Europo]. - Bull. Soc. Bot. Centre-Ouest ${ }^{\circ}$ spécial 7.

[9] Croitoru, L., Sarraf, M. (2017): Estimating the Health Cost of Air Pollution: The Case of Morocco. - Journal of Environmental Protection 8: 1087-1099. https://doi.org/10.4236/jep.2017.810069. 
[10] De Martonne, E. (1923): Aareism and aridity index [Aréisme et indice d'aridité]. Compt. Rend. Séances Acad. Sci. 181: 1395-1398.

[11] Duman, D. C., Altunkaynak, E., Aras, E. S. (2014): Heavy metal accumulation and genotoxicity indicator capacity of the lichen species Ramalina pollinaria collected from around an iron steel factory in Karabük, Turkey. - Turk. J. Bot. 38: 14.

[12] Egea, J. M. (1996): Catalogue of lichenized and lichenicolous fungi of Morocco. Bocconea 6: 19-114.

[13] Emberger, L.(1955): A biogeograpic classification of climates. - Researches and developments in Montpellier Botanical Laboratory (Une classification biogéographique des climats. Recherches et Travaux du Laboratoire de Botanique de la Faculte' des Sciences de Montpellier) 7: 3-43.

[14] Essilmi, M., Loudiki, M., ELgharmali, A. (2018): Use of calcicolous and corticolous lichens for the assessment of lead and cadmium air pollution of the Moroccan Atlantic coast Safi-Essaouira. - International Conference on Technology, Engineering and Science (IConTES), October 26-29, 2018, Antalya, Turkey, pp. 29-107.

[15] Farmer, A. M., Bates, J. W., Bell, J. N. B. (1992): Ecophysiological Effects of Acid Rain on Bryophytes and Lichens. - In: Bates, J. W., Farmer A. M. (eds.) Bryophytes and Lichens in a Changing Environment. Clarendon Press, Oxford.

[16] Frati, L., Santoni, S., Nicolardi, V., Gaggi, C., Brunialti, G., Guttova, A., Gaudino, S., Pati, A., Pirintsos, S., Loppi, S. (2007): Lichen biomonitoring of ammonia emission and nitrogen deposition around a pig stockfarm. - Environmental Pollution 146: 311316. http://dx.doi.org/10.1016/j.envpol.2006.03.029.

[17] Ferry, B. W., Coppins, B. J. (1979): Lichen transplant experiments and air pollution studies. - Lichenologist 11: 63-73.

[18] Garrec, J. P., Van Haluwyn, C. (2002): Plant biomonitoring of air quality: concepts, methods and applications [Biosurveillance végétale de la qualité de l'air: concepts, méthodes et applications]. - Tec\&Doc.117 p.

[19] Gauslaa, Y., Yemets, O. A., Asplund, J., Solhaug, K. A. (2016): Carbon based secondary compounds do not provide protection against heavy metal road pollutants in epiphytic macrolichens. - Science of the Total Environment 541: 795-801.

[20] Gilbert, O. L. (1986): Field evidence for an acid rain effect on lichens. Environmental Pollution (Series A) 40: 227-231.

[21] Giordani, P. (2006): Variables influencing the distribution of epiphytic lichens in heterogeneous areas: a case study for Liguria, NW Italy. - Journal of Vegetation Science 17: 195e206.

[22] Giordani, P. (2007): Is the diversity of epiphytic lichens a reliable indicator of air pollution? A case study from Italy. - Environmental Pollution 146: 317-323.

[23] Giordani, P., Incerti, G. (2008): The influence of climate on the distribution of lichens: a case study in a borderline area (Liguria, NW Italy). - Plant Ecology 195: 257-272.

[24] Giordani, P., Calatayud, V., Stofer, S., Seidling, W., Granke, O., Fischer, R. (2014): Detecting the nitrogen critical loads on European forests by means of epiphytic lichens. A signal-to-noise evaluation. - Forest Ecology and Management 311: 29-40.

[25] Giordani, P., Brunialti, G., Calderisi, M., Malaspina, P., Frati, L. (2018): Beta diversity and similarity of lichen communities as a sign of the times. - The Lichenologist 50(3): 371-383. DOI: 10.1017/S0024282918000221.

[26] Gottfried, M., Pauli, H., Futschik, A., Akhalkatsi, M., Barancok, P., Alonso, J. L. B., Coldea, G., Dick, J., Erschbamer, B., Ferna' ndez Calzado, M. R. et al. (2012): Continent-wide response of mountain vegetation to climate change. - Nature Climate Change 2: 111-115.

[27] Hauck, M. (2011): Site factors controlling epiphytic lichen abundance in northern coniferous forests. - Flora 206: 81-90.

[28] Hawksworth D, L., Rose, F. (1970): Qualitative scale for estimating sulphur dioxide air pollution in England and wales using epiphytic lichens. - Nature 227: 145-148. 
[29] Hickling, R., Roy, D. B., Hill, J. K., Fox, R., Thomas, C. D. (2006): The distributions of a wide range of taxonomic groups are expanding polewards. - Global Change Biology 12: 450-455.

[30] Husson, F., Josse, J., Pagés, J. (2010): Principal Component Methods-Hierarchical Clustering Partitional Clustering: Why Would We Need to Choose for Visualizing Data? - Technical Report. Agrocampus, Applied Mathematics Department, Rennes, France.

[31] Hyvarinen, M., Halonen P., Kauppi M. (1992): Influence of stand age and structure on the epiphytic lichen vegetation in the middle-boreal forests of Finland. - Lichenologist 24: $165-180$.

[32] Jaccard, P. (1908): New research on floral distribution [Nouvelles recherches sur la distribution florale]. - Bull. Soc. Vaudoise Sci. Nat. 44: 223-270.

[33] Kapusta, P., Szarek-Lukaszewska, G., Kiszka, J. (2004): Spatial analysis of lichen species richness in a disturbed ecosystem (Niepolomice Forest, S Poland). Lichenologist 36: 249e260.

[34] Lachat, T., Pauli, D., Gonseth, Y., Klaus, G., Scheidegger, C., Vittoz, P. et al. (2011): Evolution of Biodiversity in Switzerland since 1900. Have We Bottomed Out? [Évolution de la biodiversité en Suisse depuis 1900. Avons-nous touché le fond?] Édit. Fondation Bristol, Zurich.

[35] Longán, A., Gaya, E., Gómez-Bolea, A. (1999): Post-fire colonization of a Mediterranean forest stand by epiphytic lichens. - Lichenologist 31: 389-395.

[36] Loppi, S., De Dominicis, V. (1996): Effects of agriculture on epiphytic lichen vegetation in central Italy. - Isr. J. Plant Sci. 44: 297-307.

[37] Loppi, S., Frati, L., Paoli, L., Bigagli, V., Rossetti, C., Bruscoli, C., Corsini, A. (2004): Biodiversity of epiphytic lichens and heavy metal contents of Flavoparmelia caperata thalli as indicators of temporal variations of air pollution in the town of Montecatini Terme (central Italy). - Science of the Total Environment 326: 113-122.

[38] Madl, P. (2009): Anthropogenic environmental aerosols: measurements and biological implication. - Ph. D. Dissertation, University of Salzburg, Salzburg.

[39] Maizi, N., Kadri, N., Serradj, M. (2017): Absorption capacity of lead by different lichenic species. - Int. J. Biosci. 10(2): 61-71.

[40] Matos, P., Geiser, L., Hardman, A., Glavich, D. Pinho, P., Nunes, A., Soares, A. M. V. M., Branquinho, C. (2017): Tracking global change using lichen diversity: towards a global-scale ecological indicator. - Methods in Ecology and Evolution 8: 788-798.

[41] McCune, B., Geiser, L. (2009):. Macrolichens of the Pacific Northwest. 3rd Ed. Oregon State University, Corvallis, OR, USA.

[42] Ministry of Energy, Mines, Water and Environment (2014): Indicators of sustainable development in Morocco. 4th national report. - http://www.academia.edu/29606040/ Rapport_national_IDD. (accessed on 12 november 2018).

[43] Munzi, S., Pisani, T., Loppi, S. (2009a): The integrity of lichen cell membrane as a suitable parameter for monitoring biological effects of acute nitrogen pollution. Ecotoxicology and Environmental Safety 72: 2009-2012. http://dx.doi.org/10.1016/j.ecoenv.2009.05.005.

[44] Munzi, S., Pirintsos, A., Loppi, S. (2009b): Chlorophyll degradation and inhibition of polyamine biosynthesis in the lichen Xanthoria parietina under nitrogen stress. Ecotoxicology and Environmental Safety 72: 281-285. http://dx.doi.org/10.1016/j.ecoenv.2008.04.013.

[45] Nash III, T. H. (ed.) (1996): Lichen Biology. - Cambridge University Press, Cambridge, UK.

[46] New York State Urban Forestry Council Website (2018): https://nysufc.org/urbanforest-ecology-lichens-bioindicators-chemical-factories-hidden-marvels-plainsight/2018/01/25/. - Accessed on 14 November 2018. 
[47] Nimis, P. L., Martellos, S. (2017): ITALIC 5.0. The Information System on Italian Lichens. - University of Trieste, Dept. of Biology. http ://dryades.units.it/italic (accessed on 25 June 2018).

[48] Nimis, P. L., Castello, M., Perotti, M. (1990): Lichens as biomonitors of sulphur dioxide pollution in La Spezia (Northern Italy). - Lichenologist 22: 333344.

[49] Nylander, W. (1866): The lichens of the Luxembourg Garden [Les lichens du Jardin du Luxembourg]. - Bulletin de la Société botanique de France 13: 364-372.

[50] Office Chérifien des Phosphates (OCP, Morocco) (2011): Étude d'impact sur l'environnement. - Rapport_26245/EIE_PS4, 2011.

[51] Ozenda, P., Clauzade, G. (1970): Les Lichens: Étude biologique et flore illustrée. Editeur Masson et Cie, Paris.

[52] Podani, J., Ricotta, C., Schmera, D. (2013): A general framework for analyzing beta diversity, nestedness and related community-level phenomena based on abundance data. - Ecological Complexity 15: 52-61.

[53] Renaut, J., Marrache, P., Trotet, G. (1968): The notion of "Biological Spectrum" adapted to Lichens [La notion de "Spectre Biologique" adaptée aux Lichens]. - Soc. bot. Fr. 115(supl. 2, Colloque sur les lichens): 197-203.

[54] Riddell, J., Jovan, S., Padgett, P. E., Sweat, K. (2011): Tracking lichen community composition changes due to declining air quality over the last century: the Nash legacy in southern California. - Bibliotheca Lichenologica 106: 263-277.

[55] Rundel, P. W. (1988): Water Relation. - In: Galun, M. (ed.) CRC Handbook of Lichenology. Vol. II, CRC Press, Boca Raton, FL, pp. 17-36.

[56] Seaward, M. R. D. (1977): Lichen Ecology. - Academic Press, London, UK.

[57] Selva, S. B. (1994): Lichen diversity and stand continuity in the northern hardwoods and spruce-fir forests in northern New England and western New Brunswick. Bryologist 97: 424-429.

[58] Semadi, A., Tahar, A. (1995): A biological method for the detection of global pollution in the region of Annaba, Algeria [Une méthode biologique pour la détection de la pollution globale dans la région d'Annaba, Algérie]. - Pollution Atmosphérique 146: 50-58.

[59] Tievant, P. (2001): Guide to Lichens. 350 Species of Lichen from Europe [Guide des lichens. 350 espèces de lichens d'Europe]. - Delachaux and Niestlé, Lonay.

[60] Tyler, G. (1989): Uptake, retention, and toxicity of heavy metals in lichens. - Water Air Soil Poll 47: 321-333.

[61] Van den Berg, L. J. L., Vergeer, P., Rich, T. C. G., Smart, S. M., Guest, D., Ashmore, M. R. (2011): Direct and indirect effects of nitrogen deposition on species composition change in calcareous grasslands. - Global Change Biology 17: 1871-1883.

[62] Van Dobben, H. F. (1999): Ranking of epiphytic lichen sensitivity to air pollution using survey data: A comparison of indicator scales. - The Lichenologist 31: 27-39. 10.1006/lich.1998.0177.

[63] van Dobben, H. F., Wolterbeek, H. T., Wamelink, G. W. W., ter Braak, C. J. F. (2001): Relationship between epiphytic lichens, trace elements and gaseous atmospheric pollutants. Environ. - Pollut. 112: 163-169.

[64] Van Haluwyn, C., Lerond, M. (1986): Lichens and the air quality. Methodological evolution [Les lichens et la qualité de l'air. Évolution méthodologique]. - Édit. Ministère de l'environnement, SRETIE, Paris.

[65] Van Herk, C. M., Aptroot, A., van Dobben, H. F. (2002): Long-term monitoring in the Netherlands suggests that lichens respond to global warming. - Lichenologist 34: 141-154.

[66] Van Herk, K. (2001):. Bark pH and susceptibility to toxic air pollutants as independent causes of change in epiphytic lichen composition in space and time. - Lichenologist 33: 419-441. 10.1006/lich.2001.0337. 
[67] Weissman, L., Fraiberg, M., Shine, L., Garty, J., Hochman, A. (2006): Responses of antioxidants in the lichen Ramalina lacera may serve as an early-warning bioindicator system for the detection of air pollution stress. - FEMS Microbiology Ecology 58(1): 41-53.

[68] Werner, R. G., Gattefosse, J. (1931): Catalogus lichenum marocanorum adhuc cognitorum. - Bull. Soc. Sci. Nat. Maroc 11 (7-8).

[69] Werth, S., Tømmervik, H., Elvebakk, A. (2005): Epiphytic macrolichen communities along regional gradients in northern Norway. - Journal of Vegetation Science 16: 199-208.

[70] Wetmore, C. M. (1983): Lichen survival in a burned oak savanna. - Michigan Bot. 22: 4752.

[71] Whittaker, R. H. (1972): Evolution and measurement of species diversity. - Taxon 21 (2/3): 213-251.

[72] Will-Wolf, S., Geiser, L. H., Neitlich, P., Reis, A. H. (2006): Forest lichen communities and environment e how consistent are relationships across scales? Journal of Vegetation Science 17: 171e184.

[73] Wolseley, P. A., James, P. W., Theobald, M. R., Sutton, M. A. (2006): Detecting changes in epiphytic lichen communities at sites affected by atmospheric ammonia from agricultural sources. - The Lichenologist 38: 161-176.

[74] Worldwide Air Quality (2018): https://aqicn.org/country/morocco. - Accessed on 25 June 2018.

[75] World Health Organization.I

(2016): https://www.who.int/airpollution/data/aap_air_quality_database_2018_v14.xlsx. - Accessed on 25 June 2018.

\section{APPENDIX}

Table A1. Inventory of lichens harvested and identified in each site ("+” means species present)

\begin{tabular}{|c|c|c|c|c|c|c|c|}
\hline Site & Site 1 & Site 2 & Site 3 & Site 4 & Site 5 & Site 6 & Site 7 \\
\hline Distance to the industrial zone in $\mathrm{km}$ & 60 & 20 & 10 & 0 & 15 & 33 & 60 \\
\hline Libellée & Oualidia & $\begin{array}{c}\text { North of } \\
\text { Safi }\end{array}$ & $\begin{array}{c}\text { City } \\
\text { center }\end{array}$ & $\begin{array}{c}\text { Industrial } \\
\text { zone }\end{array}$ & $\begin{array}{c}\text { Safi } \\
\text { power } \\
\text { plant }\end{array}$ & Souiria & Bhibah \\
\hline Coordinates & $\begin{array}{l}32^{\circ} 43^{\prime} \mathrm{N} \\
9^{\circ} 60^{\prime} \mathrm{W}\end{array}$ & $\begin{array}{l}32^{\circ} 20^{\prime} \mathrm{N} \\
9^{\circ} 16^{\prime} \mathrm{W}\end{array}$ & $\begin{array}{l}32^{\circ} 17^{\prime} \mathrm{N} \\
9^{\circ} 14^{\prime} \mathrm{W}\end{array}$ & \begin{tabular}{|c|}
$32^{\circ} 15^{\prime} \mathrm{N}$ \\
$9^{\circ} 15.4^{\prime} \mathrm{W}$
\end{tabular} & $\begin{array}{l}32^{\circ} 10^{\prime} \mathrm{N} \\
9^{\circ} 16^{\prime} \mathrm{W}\end{array}$ & $\begin{array}{l}32^{\circ} 02^{\prime} \mathrm{N} \\
9^{\circ} 19^{\prime} \mathrm{W}\end{array}$ & $\begin{array}{l}31^{\circ} 46^{\prime} \mathrm{N} \\
9^{\circ} 34^{\prime} \mathrm{W}\end{array}$ \\
\hline Aspicilia calcarea (L.) Mudd & + & + & + & & + & + & + \\
\hline Caloplaca citrina (Hoffm.) Th. Fr. & + & + & + & + & + & + & + \\
\hline Caloplaca lactea (A. Massal.) Zahlbr. & + & + & + & + & + & + & + \\
\hline Lecania erysibe (Ach.) Mudd & + & + & + & + & + & + & + \\
\hline Xanthoria parietina (L.) Th. Fr. & + & + & + & & + & + & + \\
\hline Caloplaca aurantia (Pers.) Hellb. & + & + & + & & + & + & + \\
\hline Coscinocladium gaditanum (Clemente) A. Crespo, Llimona & + & + & + & & + & + & + \\
\hline Myriolecis dispersa (Pers.) Sliwa, Zhao Xin \& Lumbsch & + & + & + & & & + & + \\
\hline Verrucaria nigrescens Pers. & + & + & + & & + & + & + \\
\hline Verrucaria viridula (Schrad.) Ach. & + & + & + & & + & + & + \\
\hline Xanthoria calcicola Oksner & + & + & + & + & + & + & + \\
\hline Caloplaca crenulatella (Nyl.) H. Olivier & + & & + & & + & + & + \\
\hline Caloplaca erythrocarpa (Pers.) Zwackh & + & + & + & & & + & + \\
\hline Diplotomma alboatrum (Hoffm.) Flot. (éco. saxicole-calcicole) & + & + & + & & & + & + \\
\hline Lecania spadicea (Flot.) Zahlbr. & + & + & + & & & + & + \\
\hline Myriolecis albescens (Hoffm.) Sliwa, Zhao Xin \& Lumbsch & + & + & + & & & + & + \\
\hline Myriolecis crenulata (Hook.) Sliwa, Zhao Xin \& Lumbsch & + & + & + & & & + & + \\
\hline Acrocordia conoidea (Fr.) Körb. & + & + & & & & + & + \\
\hline Arthonia calcarea $(\mathrm{Sm}$.$) Ertz \& Diederich$ & + & + & & & & + & + \\
\hline Bagliettoa calciseda (DC.) Gueidan \& Cl. Roux & + & + & & & & + & + \\
\hline
\end{tabular}


Parabagliettoa cyanea (A. Massal.) Gueidan et Cl. Roux

Physcia adscendens (Fr.) H. Olivier

Alyxoria subelevata (Nyl.) Ertz \& Tehler

Buellia dispersa A. Massal.

Caloplaca chalybaea (Fr.) Müll. Arg.

Caloplaca subochracea (Wedd.) Werner

Diploicia canescens (Dicks.) Massal

Lecania atrynoide $\mathrm{M}$. Knowles

Myriolecis bandolensis. Bertrand, $\mathrm{Cl}$. Roux et Nimis

Rocella phycopsis Ach.

Dirina massiliensis (A. Massal.) Tehler

Alyxoria variiformis (Anzi) Ertz

Opegrapha rupestris Pers.

Ramalina pollinaria (Westr.) Ach.

Toninia aromatica (Sm.) A. Massal.

Diploschistes scruposus (Schreb.) Norman

Total number of species per site

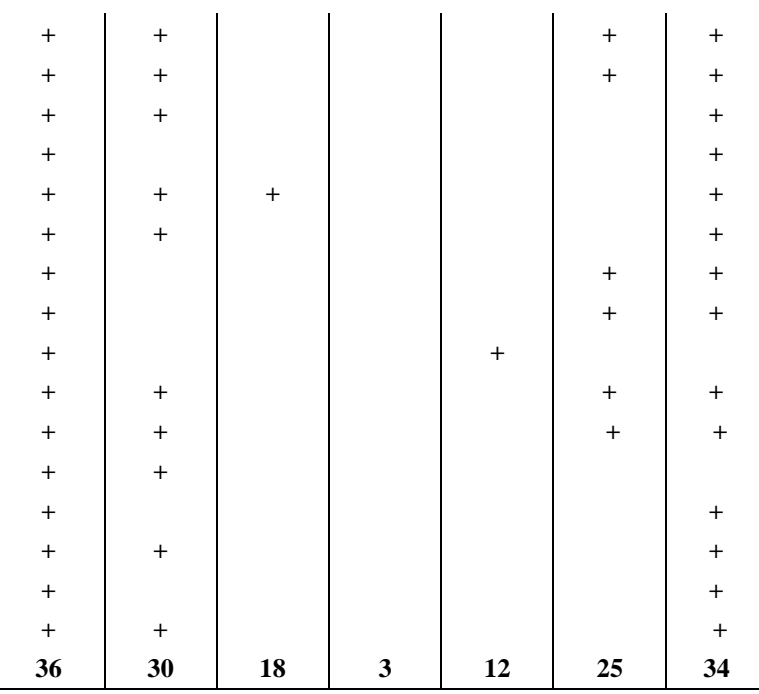

Table A2. Poleotolerance indice (PI) and eutrophication indice (EI) of calcicolous species harvested

\begin{tabular}{|c|c|c|}
\hline Identified species & PI & EI \\
\hline Acrocordia conoidea (Fr.) Körb. & 1 & 1 \\
\hline Alyxoria variiformis (Anzi) Ertz & 1 & 1 \\
\hline Alyxoria subelevata (Nyl.) Ertz \& Tehler & $1-2$ & $1-3$ \\
\hline Arthonia calcarea $(\mathrm{Sm}$.$) Ertz \& Diederich$ & $1-2$ & $1-3$ \\
\hline Aspicilia calcarea (L.) Mudd & $2-3$ & $2-3$ \\
\hline Bagliettoa calciseda (DC.) Gueidan \& Cl. Roux & 1 & $1-2$ \\
\hline caloplaca aurantia (Pers.) Hellb. & $1-3$ & $3-4$ \\
\hline Caloplaca chalybaea (Fr.) Müll. Arg. & $1-3$ & $2-3$ \\
\hline Caloplaca citrina (Hoffm.) Th. Fr. & $1-3$ & $4-5$ \\
\hline Caloplaca crenulatella (Nyl.) H. Olivier & $1-2$ & 4 \\
\hline Caloplaca erythrocarpa (Pers.) Zwackh & $1-2$ & $2-3$ \\
\hline Caloplaca lactea (A. Massal.) Zahlbr. & $1-3$ & $2-3$ \\
\hline Caloplaca subochracea auct. & 1 & $1-2$ \\
\hline Coscinocladium gaditanum (Clemente) A. Crespo, Llimona \& D. Hawksw. & $1-2$ & $2-3$ \\
\hline Diplotomma alboatrum (Hoffm.) Flot. (éco. saxicole-calcicole) & $1-2$ & $3-4$ \\
\hline Dirina massiliensis (A. Massal.) Tehler & 1 & $1-2$ \\
\hline Lecania erysibe (Ach.) Mudd & $1-3$ & $4-5$ \\
\hline Lecania spadicea (Flot.) Zahlbr. & $1-2$ & $3-4$ \\
\hline Myriolecis albescens (Hoffm.) Sliwa, Zhao Xin \& Lumbsch & $1-3$ & $3-4$ \\
\hline Myriolecis crenulata (Hook.) Sliwa, Zhao Xin \& Lumbsch & 1 & $1-2$ \\
\hline Myriolecis dispersa (Pers.) Sliwa, Zhao Xin \& Lumbsch & $2-3$ & $2-4$ \\
\hline Parabagliettoa cyanea (A. Massal.) Gueidan et Cl. Roux & 1 & 1 \\
\hline Physcia adscendens (Fr.) H. Olivier & $1-3$ & $3-5$ \\
\hline Ramalina pollinaria (Westr.) Ach. & $1-2$ & $2-4$ \\
\hline Rocella phycopsis Ach. & $1-2$ & $1-3$ \\
\hline Toninia aromatica $(\mathrm{Sm}$.$) A. Massal.$ & $1-3$ & $2-4$ \\
\hline Verrucaria nigrescens Pers. & $1-3$ & $2-5$ \\
\hline Verrucaria viridula (Schrad.) Ach. & $1-2$ & $3-4$ \\
\hline Xanthoria calcicola Oxsner & $1-2$ & $4-5$ \\
\hline Xanthoria parietina (L.) Th.Fr. & $1-3$ & $3-4$ \\
\hline Buellia dispersa A. Massal. & 1 & $2-3$ \\
\hline Diploicia canescens (Dicks.) Massal & $1-2$ & $2-4$ \\
\hline Diploschistes scruposus (Schreb.) Norman & $1-2$ & $1-3$ \\
\hline Lecania atrynoides M. Knowles & 1 & $2-3$ \\
\hline Myriolecis bandolensis (B. de Lesd.) Bertrand, Cl. Roux et Nimis & 1 & $2-4$ \\
\hline Opegrapha rupestris Pers. & $1-2$ & $1-2$ \\
\hline
\end{tabular}

